\title{
Reliability cost/worth assessment of distribution network formed by underground cables and overhead lines. Case study of Latvia
}

\author{
Aleksandrs L̦vovs,

\section{Ilze Priedite} \\ Laboratory of Mathematical Modelling \\ of Power Systems/Laboratory of Power \\ System Analysis and Optimization, \\ Institute of Physical Energetics, \\ 21 Aizkraukles Street, \\ Riga, LV-1006, Latvia \\ E-mail: aleksandrs.lvovs@inbox.lv; \\ prieditei@inbox.lv
}

The increasing number of severe weather occurrences that influence the number of large scale outages, especially in rural distribution networks, makes the question on the need of increasing reliability level of power supply of the distribution network even more actual. Distribution system operators and national regulators shall not only find a reliable but also a cost-effective solution for further distribution network development: the optimal reliability level of power supply.

One of the reliability improvement solutions that allows effectively dealing with the reduction of the number of outages in rural distribution networks is the cablification of network. Construction costs of the aforementioned solution are quite high in comparison to other network line types, and due to that, the implementation of the solution always raises discussions on cost-effectiveness.

The paper presents approaches for the cost/worth assessment of power line lifetime costs in the distribution network and for the assessment of customer costs of reliability that takes into account time-varying loads and outage costs (previously developed by authors of this paper $[6,7]$ ) as well as for the assessment of traders' losses due to electrical energy not supplied.

The case study included in the paper is performed for Latvian conditions and takes into account information on the real customer costs of reliability of Latvian customers (information from the study of the Institute of Physical Energetics), fault statistics of Latvian underground cables and overhead lines, information with a high level of details on the capital costs, operational and fault elimination costs of distribution lines in Latvia.

Key words: cost/worth assessment, power distribution lines, power system economics, power system reliability

\section{INTRODUCTION}

The role of power quality and supply reliability increases over the years, as modern society becomes more dependent on electrical appliances with high technical requirements. Electric power quality and supply reliability are closely related to each other and sometimes have the same causes of appearance, e. g. trees can cause both voltage dips and temporary as well as permanent 
faults of overhead lines [1]. Over the past few years, events of power supply interruption in Latvia raised the question of power system reliability.

Improvement of power supply reliability can be achieved by three major groups of activities:

- Activities that decrease the amount of faults/ outages;

- Activities that decrease the amount of customers experiencing power supply interruption;

- Activities that decrease the duration of power supply interruption.

In the case of usage of bare wire overhead lines, especially in forest territories, there are the following possible solutions for reliability improvement of the distribution network:

- Usage of isolated wires (helpful for shortterm interruptions);

- Higher sectionalizing of line - decreasing the length of each section;

- Creation of a meshed network;

- Network automatization: automatic reclosers and circuit breakers with a possibility of remote control;

- Network automatization: usage of a greater amount of fault indicators with internet connection to the GIS system;

- Construction of low cost $110 / 20 \mathrm{kV}$ primary stations and $110 \mathrm{kV}$ lines;

- Usage of underground cables.

From all the mentioned activities, the usage of underground cables deals with the improvement of reliability in the most effective way. High investment costs, compared to construction costs of overhead lines, are usually mentioned as a disadvantage of the cablification initiatives (DSO investment programs). However, according to the authors' opinion, there is a need to not only evaluate the investment costs in the network but also maintenance costs of the network as well as customer costs of reliability and traders' losses due to electrical energy not supplied.

In order to minimize the negative effect of "bad weather" and improve power quality, Latvian DSO - AS "Sadales tikls" decided to launch the so-called Cablification Program. In the frame of the program, it is planned to replace $6000 \mathrm{~km}$ of medium-voltage overhead lines that are placed in the forest by cable lines. The AS "Sadales tikls" Cablification Investment Program for the period
2014-2023 is even included in the Energy Development Guidelines for the years 2014-2020, prepared by the Ministry of Economics of the Republic of Latvia [2].

The analysis and comparison of different long-term network development strategies, taking into account reliability of power supply, is a topical issue, and a variety of papers are devoted to the topic abroad. The analysis and comparison of different network development options using CAPEX, OPEX and outage costs is performed, e. g. in [3]. According to Finnish colleagues, where the climate is comparable to the Latvian network, the medium-voltage network is the cause of $90 \%$ customer-experienced outages; due to this fact, the main attention shall be paid particularly to the medium-voltage distribution network. Previously, underground cabling in rural areas has not been considered economically grounded, but using appropriate cabling strategy can also be economical [4]. Customer costs of reliability have already been a topical issue for the regulation of the quality of distribution network power supply in Norway back in 2001 [5]. Unfortunately, the authors were unable to find any papers regarding distribution network development strategies for Latvia that would consider reliability of power supply and customer costs of reliability, except the authors' own papers $[6,7,14]$ and one recently presented paper by a student of Riga Technical University [22] that gives some valuable information on Latvian distribution network outages and cost calculations of the Distribution System Operator (DSO). Yet, it does not take into account real Latvian customer costs of reliability. Methodology for traders' losses due to energy not supplied presented in [22] also has some drawbacks.

Due to the aforementioned facts, in the paper, authors briefly present approaches for the cost estimation of utility related to construction and maintenance of the network as well as the approach for the estimation of customer costs of reliability (already presented in [6,7]) and supplement them with the approach that takes into account traders' losses due to energy not supplied. All the approaches have been developed by the authors of the paper based on the theoretical and practical experience in the field of electrical networks. 
The paper includes a case study performed on a typical medium-voltage network scheme and, what is the most important and has not been done previously in studies for Latvia, using as much as possible of the data on the Latvian distribution system outage statistics, customer costs of reliability and energy price, as well as imbalance prices in Latvia.

\section{APPROACHES FOR ESTIMATION OF UTILITY COSTS, CUSTOMER COSTS OF RELIABILITY AND TRADERS' LOSSES}

\section{Approach for cost estimation of utility}

For comparison of economic performance of the networks formed by different types of power lines, e. g. overhead lines (OHL) or cable lines (CL), from the point of view of construction, maintenance and fault elimination costs, detailed data on the number of maintenance works, failure rates, costs of materials and work, etc. should be known. These data are used in the algorithm of methodology for cost estimation (see Fig. 1a). The algorithm diagram and equations for calculation of $C L$ and OHL total costs are described in detail in [6].
In a common situation, expenses related to construction and operation of the network can be calculated using (1)

$$
C=\sum_{i=1}^{n}\left(C_{i}+C_{i m}+C_{f e . i}\right)
$$

where $C$ is the total costs of the network for a period of time, monetary units/time period; $C i$ is the total construction costs of lines with parameters $i$, monetary units; $C_{m i}$ is the total preventive repair/maintenance costs of lines with parameters $i$, monetary units; $C_{\text {fe.i }}$ is the total fault elimination costs for lines with parameters $i$, monetary units; $i$ is the number, corresponding to the power line with specific parameters; $n$ is the total number of lines with different parameters used for the network.

Equation (1) gives the total costs of the network for some period of time, e. g. one year or lifetime of power lines, taking into account the power line life time and different costs for lines of the same type (OHL, CL, or other types of lines), but different parameters, e. g. cross section [7].

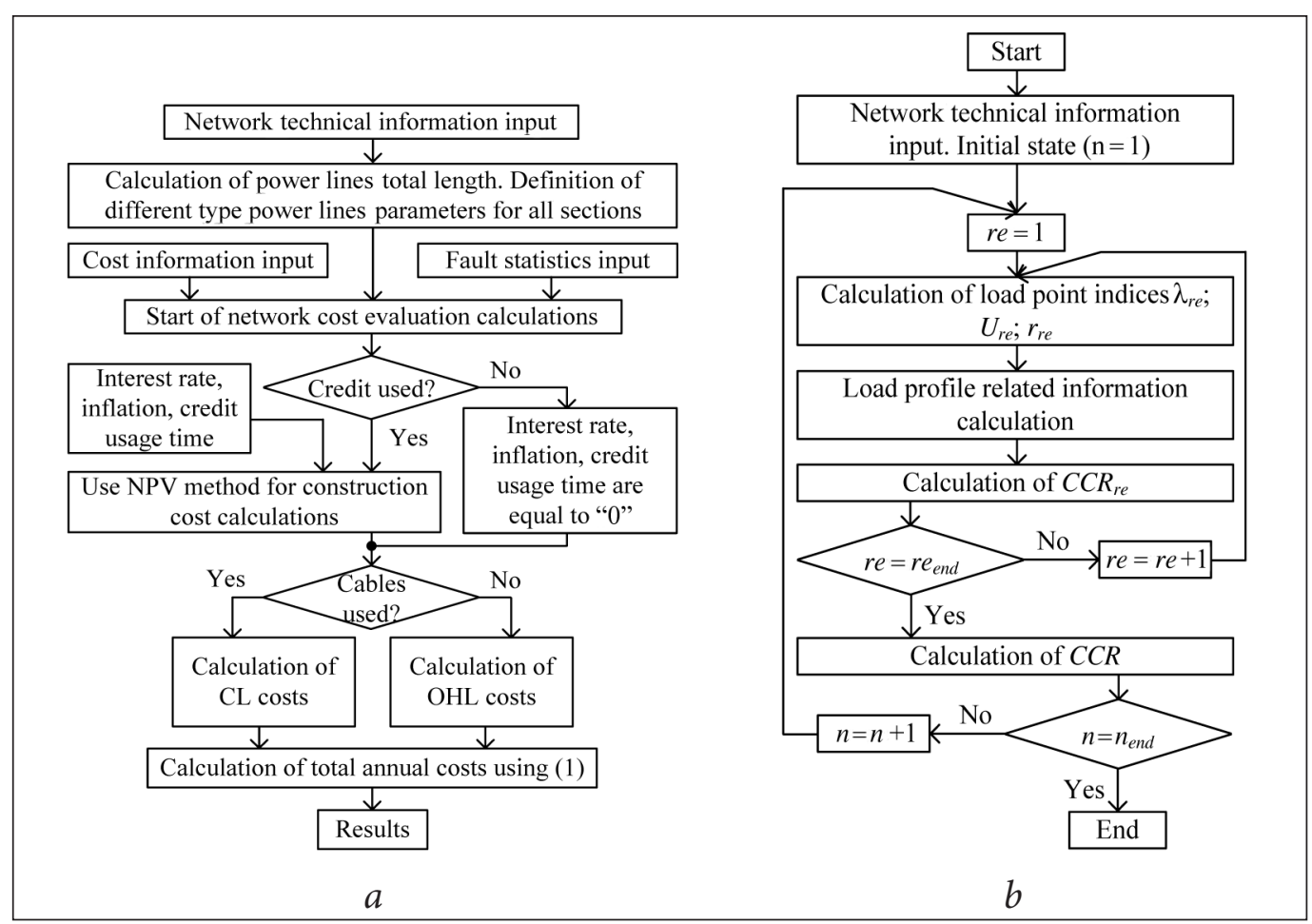

Fig. 1. $a$ is the algorithm for cost estimation methodology; $b$ is the customer costs of the reliability calculation flowchart $[6,7]$ 


\section{Approach for estimation of customer costs of reliability}

In most cases, the analysis of customer costs of reliability (further CCR) and energy not supplied (further ENS) is performed using average loads. In such case, energy consumption is replaced by the average load of the load point during some long period of time - season, like in [8], year, like in [9], or other time period, like in [10]. For calculation of the ENS the average load of the year/ season/other period is multiplied by the average power supply interruption time of customers.

According to the results of surveys of customer costs related to power supply interruptions, the costs are not constant, and they change not only in terms of seasons of a year but also in short time periods - month and time of a day [11-13]. The same tendency was approved also for Latvian customers during the study performed by one of the authors during the research work in the Institute of Physical Energetics [14].

Usually, the reason of power supply interruption cost changes during time is supposed to be changes of load values. In order to verify the assumption, a comparison of ENS changes and CCR changes during a day (24-hour period) was made. Possible ENS values for each hour of a day were calculated taking into account the average duration of power supply interruption (that was $\sim 8.5$ hours in Latvia in the summer of the year 2010, but during the summer of 2011 it was $\sim 7$ hours [15]), information about typical load diagrams of the sector customers [16] and statistical data about sector energy consumption [17]. The comparison showed that CCR changes did not always correspond to ENS (therefore, load) changes.

This was the reason for development of a methodology that takes into account time-varying loads and customer costs.

The proposed approach for evaluation of CCR is based on the evaluation of the effect of interruptions occurring at the distribution network level. This can be based on the fact that according to statistical data [18], power supply interruptions are caused mainly by outages in the distribution network.

The flowchart given in Fig. 1b illustrates the structure of the proposed approach. A brief description of the approach is given further, but a detailed description of the approach is given in $[6,7]$.
Before calculation starts, information about the network that includes failure rates of network elements, load diagrams, protection devices, etc. is specified. As soon as calculations can be carried out for different network configurations (states), e. g. different types of lines, number of reclosers, etc., information about the network state number (indicated by $n$ ) is also given.

After the network technical information for the state $n$ is known, calculations start. Taking into account that customer load diagrams as well as failure rates of elements usually depend on time, different network operation modes re should be assumed. Regimes re represent such network operation modes like working days in winter or other seasons, holidays in winter and other seasons, etc.

When the number of regimes is known, calculation of load point indices starts. During this process, values of failure rate $\lambda_{r e}$, unavailability $U_{r e}$ and average power supply restoration time $r_{r e}$ for each load point are calculated based on network configuration (state) $n$ and regime $r e$.

To calculate CCR for the regime re, ENS and interrupted load for each hour of a 24 hour (a day) period are calculated. CCR is calculated based on the information of each hour ENS and interrupted load. CCR is formed by costs caused by short-term (<3 $\mathrm{min})$ and long-term $(>3 \mathrm{~min})$ power supply interruptions and can be calculated using (2)

$$
C C R=C C R_{s}+C C R_{l}
$$

where $C C R_{s}$ is the customer costs of reliability caused by short-term ( $<3 \mathrm{~min})$ power supply interruptions, monetary units; $C C R_{l}$ is the customer costs of reliability caused by long-term ( $>3 \mathrm{~min}$ ) power supply interruptions, monetary units.

In comparison to [22], in this study, real customer costs of reliability have been used. Costs from short-term and long-term interruptions have been taken into account.

According to international studies, shortterm interruptions have the same importance as long-term interruptions. In the study performed by Norwegian specialists from SINTEF, energy research and NVE stated that the monetary effect on consumers caused by short-term 
interruptions is estimated to be in the same level in comparison to customer costs due to interruptions with long duration [19]. The other paper raises another topical issue related to short-term interruptions and sags - in the existing situation, power distribution utilities do not pay as much attention to short-term interruptions and sags as they do to the longer lasting interruptions (with duration $>3 \mathrm{~min}$ ). However, such interruptions also seriously affect the operation of electrical equipment by initiating restarts of the operational process. Due to the high frequency of such events, significance of short-term interruptions may be even higher compared to long interruptions [20]. A survey performed in Korea showed that more than $70 \%$ of respondents (of all customers with damage) indicated that they experienced interruptions with short-term duration [21].

The number of short-term interruptions in the Latvian $20 \mathrm{kV}$ network treated by auto-reclosing in the year 2013 was as high as 7000 events [22]. Using the length of $20 \mathrm{kV}$ network power lines in forest territories $(13528 \mathrm{~km})$, where shortterm interruptions mainly occur, the number of short-term interruptions can be estimated at the level of 51.74 interruptions $/ 100 \mathrm{~km} /$ year. Comparing the short-term interruption frequency statistics to the Latvian real long-term fault frequency statistics of overhead lines (with bare wire) - 24.39 interruptions $/ 100 \mathrm{~km} /$ year and cable lines - 3.03 interruptions $/ 100 \mathrm{~km} /$ year, one can see that in the Latvian situation, damage resulted from short-term interruptions is also worth to be analysed.

The study "Estimation of Power Supply Interruption Costs for Latvian Customers" performed by one of the authors approves significance of short-term interruptions, especially for Industry and Commercial Service sectors, by indicating high power supply interruption costs [14]. It is worth noting that the aforementioned study is almost the only full-scale study of this kind if not in the Baltic States, then definitely in Latvia. Only two similar studies in the Baltics are known to the authors: the first was performed in 1976 [23]; the second was performed by the Tallinn University of Technology recently, but because of time constraints, the second study shall be considered more as a pilot survey [24].
Approach for estimation of electricity traders' losses due to electrical energy not supplied

According to the existing market setup in the Baltic States, electricity traders plan (forecast) consumption of their clients for the next day and buy the appropriate amount of electricity in the day-ahead market operated by the Nord Pool Spot AS (NPS market). In the case of power supply interruption, a certain amount of consumption is disconnected from the network. This results in an unpredicted surplus of electricity for some traders, as they have lost a certain amount of their client load.

There are two possible ways of selling excess power. One way is to try to sell excess power at the Intraday market (Elbas), where bids shall be put at least one hour and 15 minutes before a trading hour. Another option is to sell the excess power to the Transmission Network Operator as imbalance power. The second option is the most probable because traders usually do not have online information on their clients.

The authors propose the following approach for estimation of traders' losses due to electrical energy not supplied. Traders' losses due to electrical energy not supplied can be found as the amount of not supplied energy multiplied by the price difference of energy price offered at the market and the price of energy offered by TSO from a trader at the balancing market:

$$
\begin{aligned}
& C_{\text {traders }}=\left(\mathrm{P}_{\text {middle }}{ }^{*} \lambda_{\text {middle }}{ }^{*} \mathrm{t}_{\text {middle }}+\right. \\
& \left.+P_{\text {long }}{ }^{*} \lambda_{\text {long }}{ }^{*}{ }_{\text {long }}\right)^{*}\left(C_{\text {market }}-C_{\text {balancing }}\right),
\end{aligned}
$$

where $C_{\text {traders }}$ is traders' losses due to electrical energy not supplied, $€ ; P_{\text {short }}, P_{\text {long }}$ are the average power interrupted during the middle and longterm interruptions, $\mathrm{kW} ; \lambda_{\text {short }}, \lambda_{\text {long }}$ are the number of short-term and long-term interruptions per client; $t_{\text {short }}, t_{\text {long }}$ are the duration of shortterm and long-term interruptions, $\mathrm{h} ; C_{\text {market }}$ is the $\mathrm{D}-1$ market price of energy, $€ / \mathrm{kWh} ; C_{\text {balancing }}$ is the price of energy offered by TSO from a trader, $€ /$ kWh.

A similar approach was proposed by Moldrik P. et al. in the paper "Problems of Deployment of RC Switching Elements in Distribution MV Networks for Improving Reliability of Power Supply" [25]. 


\section{CASE STUDY}

The aim of the case study was to estimate the total costs of reliability that would include the estimated utility costs related to construction and operating costs of networks with OHL and CL, the estimated customer costs of reliability due to changes in network reliability as well as the estimated traders' losses due to electrical energy not supplied for the OHL and CL formed distribution network.

\section{Description of the network used for the case study}

For the case study, a medium voltage network scheme has been used that takes into account a typical structure of medium voltage distribution networks used in Latvia [26]. The network used in case studies is shown in Fig. 2. It has a power supply from two different $110 / 20 \mathrm{kV}$ substations placed in rural territory. The main feeder that goes between the substations is divided into two identical parts with tie circuit breaker (TCB) and connected to the substations via circuit breakers (CB). The case study was made only for half of the feeder (this half consists of sections L1 and L2 and is seen in Fig. 2), but reliability calculations (that have been performed to evaluate customer costs of reliability) take into account reservation possibilities from the other half of the feeder.
For reliability improvement reasons, sectionalizing disconnectors are also installed. In case of faults at some section of the feeder, there is a possibility to disconnect a faulted part. In such case, each half of the main feeder is divided into 2 parts: L1 (length $6 \mathrm{~km}$ ) and L2 (length $6 \mathrm{~km}$ ). Each branch $-l_{11}, l_{12}$, etc. has the length of $6 \mathrm{~km}$.

For reliability calculations, reliability of transformers and sectionalizing disconnectors has not been taken into account. Failure rates of overhead lines and underground cable lines have been taken from [22].

According to the Protection Zone Law of Latvia [27], in Latvia the so-called "protection zones" are defined as certain areas, the task of which shall be to protect different types of objects (natural, as well as artificial) from undesirable external effects, to ensure the operation and safety thereof or to protect the environment and people from the harmful effect of an object. A protection zone of power line shall be cleaned of trees and bushes. This law defines the following protection zones for the overhead lines and underground cable lines: $13 \mathrm{~m}$ and $2 \mathrm{~m}$, respectively. Trimming of routes was assumed to be done once per 4 years.

Additional information used for the case study Taking into account that case studies included not only calculations of utility costs related to the network construction and maintenance but also customer costs of reliability, there was a need for

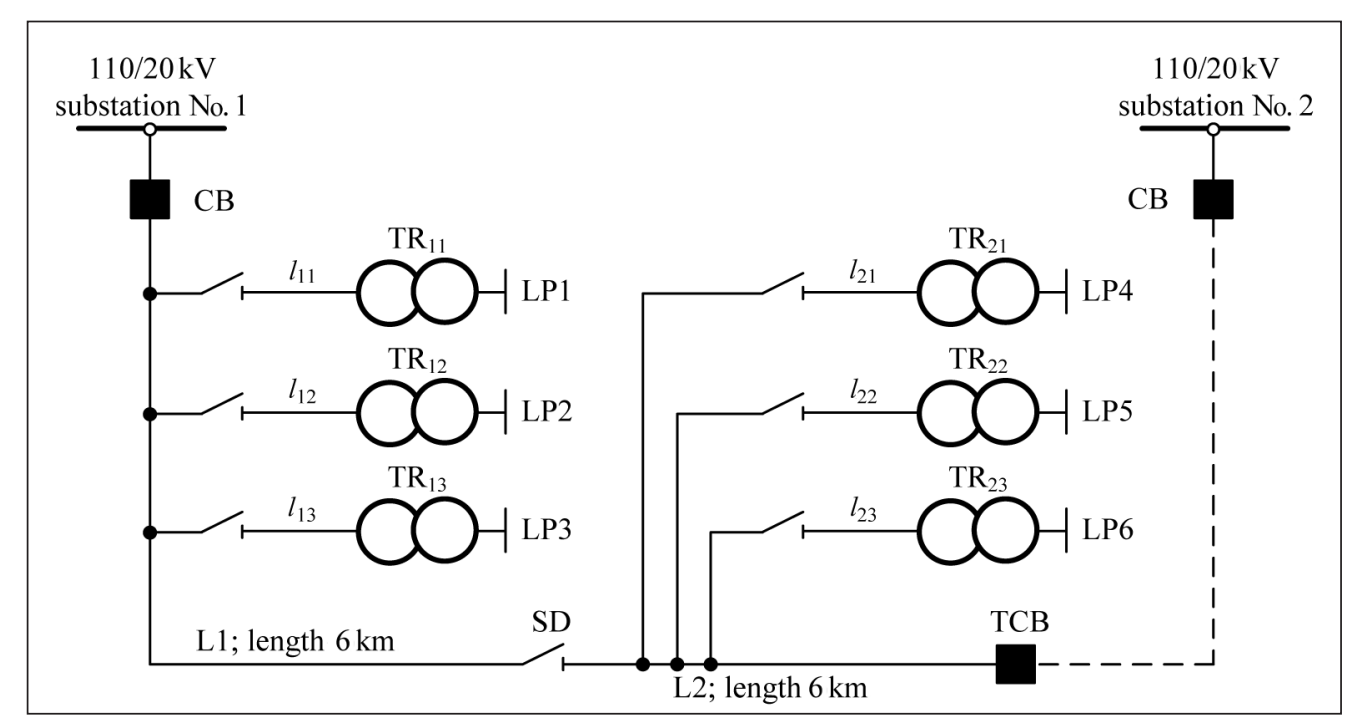

Fig. 2. The medium-voltage distribution network used in case studies 
information about the network construction and maintenance costs as well as information about the power supply restoration time and the timevariable customer costs of reliability.

Construction and maintenance costs have been obtained from the Latvian DSO "Sadales tikls" and private companies that construct and help to maintain the network in the operating state [28].

In Latvia, the average power supply interruption time during the summer of 2010 was $\sim 8.5$ hours, but during the summer of 2011 it was approximately 7 hours [29]. Decrease of the power restoration time is explained by improvements in network protection and automation systems that help to restore the network faster than in previous times. Due to this fact, it was assumed that power supply interruption could be eliminated in 7 hours not only in summer but also in other seasons of the year. Time needed for manual switching off the disconnector was assumed one hour.

Information about time-variable customer costs of reliability was taken from the study "Estimation of Power Supply Interruption Costs for Latvian Customers" performed by one of the authors [14]. In calculations, cost variation depending on season and working/not working hours was taken into account. Also it was assumed that at each load point - LP1, LP2, etc. maximal active load is $150 \mathrm{~kW}$. Each load point included the load from the three main consumption sectors - Commerce and Service Sector; Industry Sector; and Household Sector with the shares of load at the load point: $43 \% ; 28.7 \%$ and $28.3 \%$, respectively. Load diagrams for the sectors were constructed using information about the load diagrams of Latvian consumers [30].

Customer costs of reliability have been estimated, including costs created by permanent faults (power supply interruption time $>3 \mathrm{~min}$ ) when there is a need for a repair (long-term faults) or switching (medium-term faults) for power supply restoration and short-term faults (power supply interruption time $\leq 3 \mathrm{~min}$ ).

For calculatio;ns of traders' losses due to electrical energy not supplied, the information on the average balancing price of the Latvian TSO "Augstsprieguma tikls" and the average energy price on the Nord Pool Spot AS day-ahead (Elspot) market in 2014 was used [31, 32].

The case study included two options:
- Network is fully formed by OHL;

- Network is fully formed by CL.

In addition to the previously mentioned replacement of OHL with CL, the authors of the paper decided to analyze the effect of taking credit for network construction on network construction costs and, as a result, on total costs of reliability. In calculation, it was assumed that the credit is taken for 30 years, the interest rate is $7 \%$ and the inflation is 3\%. The life cycle of underground cable lines is assumed 45 years, but for the rest types of lines it is 30 years.

\section{RESULTS AND DISCUSSION}

The results of reliability cost/worth assessment of the distribution network are presented in this section.

Table 1 gives information about annual costs (in thousands of EUR) of DSO related to the construction, maintenance and fault elimination for the CL and OHL network.

Table 1. Annual costs of DSO

\begin{tabular}{c|c|c|c|c}
\hline \multirow{2}{*}{ Costs, thous. EUR } & \multicolumn{2}{|c|}{ With credit } & \multicolumn{2}{c}{ Without credit } \\
\cline { 2 - 5 } & $\begin{array}{c}\text { Cable } \\
\text { line }\end{array}$ & $\mathbf{O H L}$ & $\begin{array}{c}\text { Cable } \\
\text { line }\end{array}$ & OHL \\
\hline $\begin{array}{c}\text { Construction } \\
\text { costs (CAPEX) }\end{array}$ & 118.55 & 82.10 & 37.80 & 26.18 \\
\hline $\begin{array}{c}\text { Maintenance } \\
\text { costs (OPEX) }\end{array}$ & 4.39 & 22.39 & 4.39 & 22.39 \\
\hline $\begin{array}{c}\text { Fault elimina- } \\
\text { tion costs }\end{array}$ & 1.70 & 10.39 & 1.70 & 10.39 \\
\hline Total: & 124.64 & 114.88 & 43.89 & $\mathbf{5 8 . 9 6}$ \\
\hline
\end{tabular}

Table 2 gives information about the annual costs (in thousands of EUR) of clients related to short-, medium- and long-term outages for the CL and OHL network.

Table 2. Annual costs of clients

\begin{tabular}{ccc}
\hline Costs, thous. EUR & Cable line & OHL \\
\hline Short-term outages & 0.00 & 78.05 \\
\hline Medium-term outages & 5.94 & 47.85 \\
\hline Long-term outages & 7.03 & 56.62 \\
\hline Total: & $\mathbf{1 2 . 9 8}$ & $\mathbf{1 8 2 . 5 2}$ \\
\hline
\end{tabular}

Table 3 gives information about the annual costs (in EUR) of energy traders related to middle and long outages for the CL and OHL network. 
As can be seen from Table 3, results for annual energy traders' costs are with the “_” (minus) sign. This means that energy traders benefit from power supply interruptions. Such results can be explained by the fact that the average price on the balancing market during the taken period (year 2014) was higher (57.58 EUR/MWh) than the energy market price on the day-ahead market (50.08 EUR/MWh). Such situation appears when the power system on average is in the deficit state and power supply interruption that reduces consumption of the system is beneficial for traders.

Anyway, it should be noted that the amount of energy trader costs (or profit, as in this case) is not comparable to the costs of DSO and clients.

Table 3. Annual energy trader costs

\begin{tabular}{ccc}
\hline Costs, EUR & Cable line & OHL \\
\hline Middle outages & -4.70 & -37.80 \\
\hline Long outages & -10.96 & -88.20 \\
\hline Total: & $\mathbf{- 1 5 . 6 5}$ & $\mathbf{- 1 2 5 . 9 9}$ \\
\hline
\end{tabular}

Figures 3 to 5 present the results of calculations in a graphical format, which makes it easier for comparison.

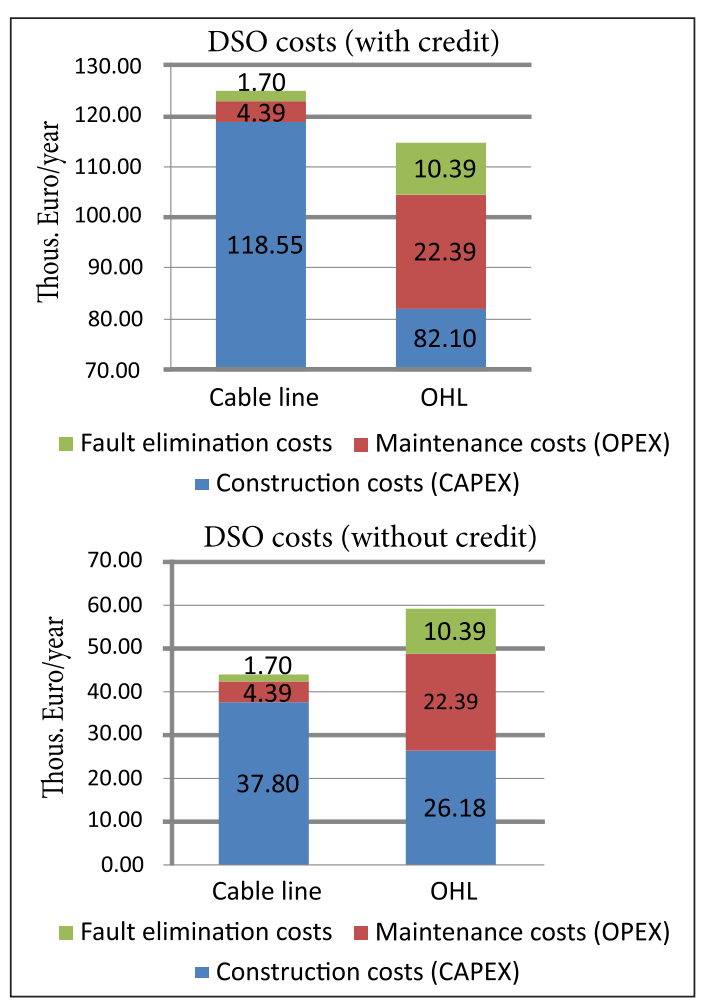

Fig. 3. DSO annual costs related to the construction, maintenance and fault elimination for the $\mathrm{CL}$ and $\mathrm{OHL}$ network
As can be seen from the results (Fig. 3), the maintenance and fault elimination costs for the OHL network are much higher compared to cable networks. Even taking credit for network construction, purely DSO costs are only $\sim 8 \%$ higher compared to the OHL network costs.

Figure 4 shows a huge difference in customer costs for the OHL and CL comparison. Results show the importance of short-term outages $(<3 \mathrm{~min})$, as they result in nearly half of all client costs for the case in the OHL network.

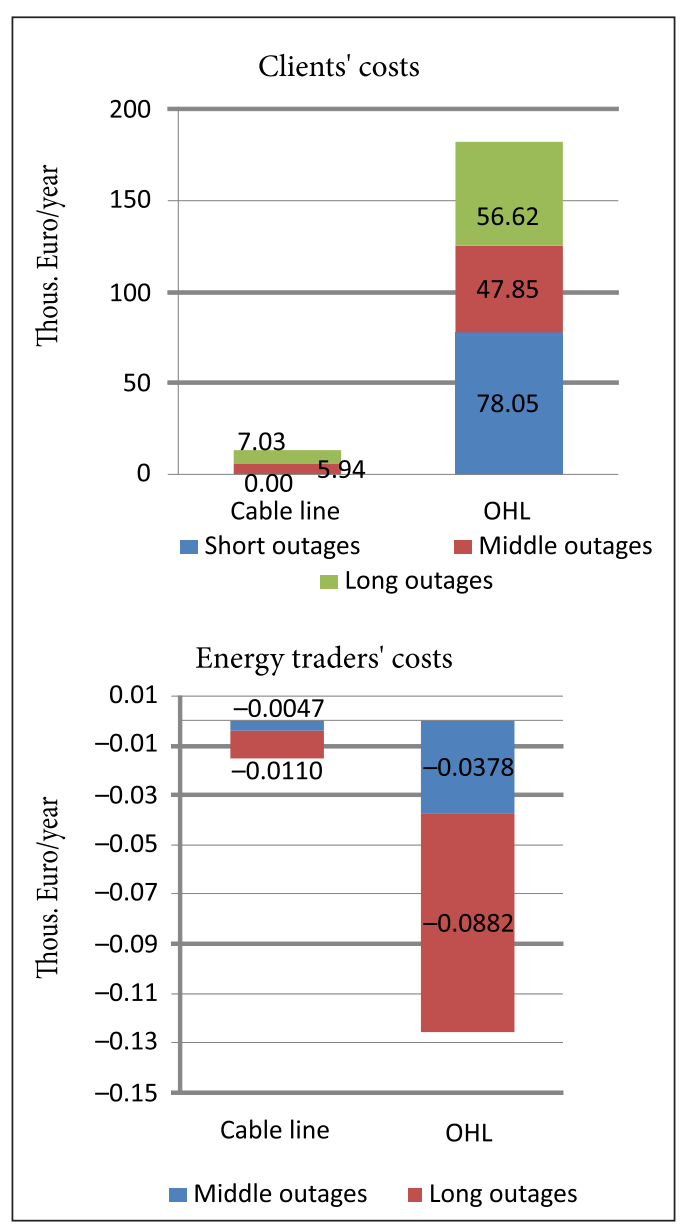

Fig. 4. Clients' (on the left side) and energy traders' (on the right side) annual costs

The main results are shown in Fig. 5 - total costs of all parties. The results clearly show economical and reliability benefits of cable line usage in the distribution network in Latvia. This means that the aforementioned investment (cablification) program of the AS "Sadales tikls" is worth spending money. 


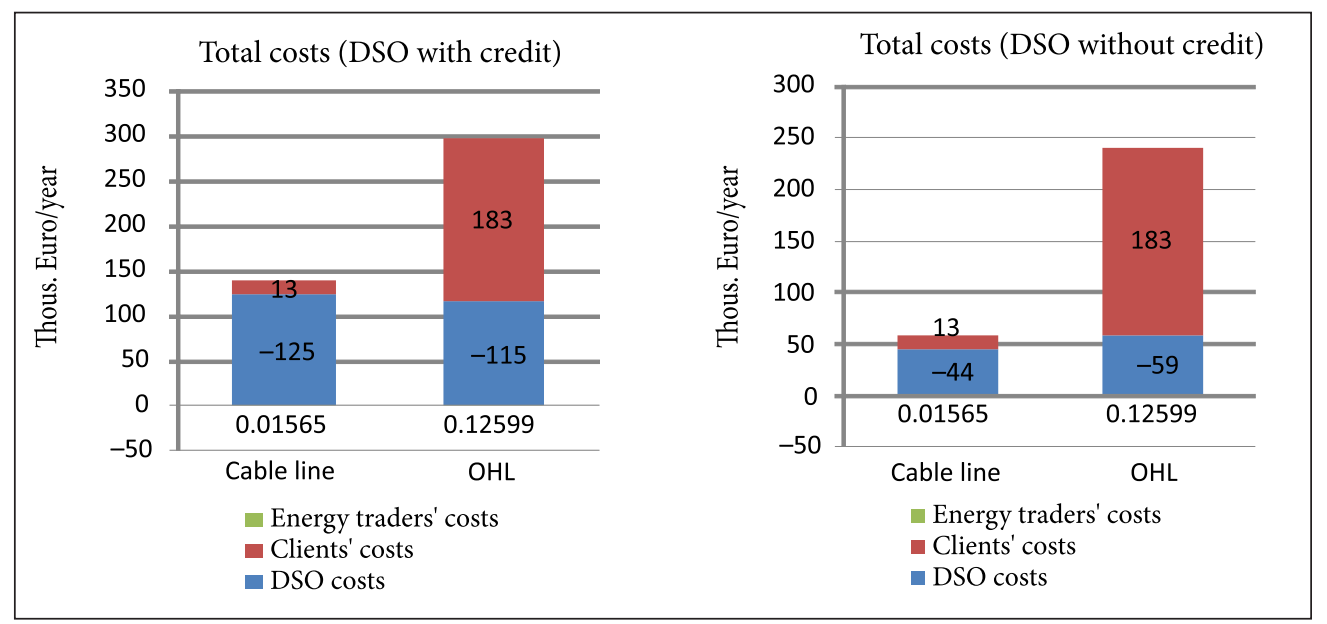

Fig. 5. Total annual costs of DSO, clients and energy traders. DSO with credit (on the left side) and DSO without credit (on the right side)

\section{CONCLUSIONS}

Power system economics is an important topic for DSOs and regulatory institutions, especially when making decisions about starting a new largescale investment program.

The case study, using the Latvian typical distribution network structure and Latvian statistical data on outages, customer costs and power energy prices, has been carried out. The study showed clear benefits of using underground cable lines instead of overhead lines in the forest territories in Latvia.

On the basis of the calculation results, it can be stated that short-term outages ( $<3 \mathrm{~min}$ ) are as much important and have a significant economic impact on electricity consumers as medium-term and long-term outages.

Another important conclusion following from the study is that according to the results of calculations, electricity trader losses due to energy not supplied may be neglected.

Received 26 February 2015 Accepted 8 May 2015

\section{References}

1. Brown R. E. Electric Power Distribution Reliability. New York: Marcel Dekker Inc., 2002. P. 40-114.

2. Energétikas attīstīibas pamatnostādnes 2014. 2020. gadam (Informatīvā dal̦a) (in Latvian). Ekono- mikas ministrija Rīga, 2014. https://em.gov.lv/ lv/nozares_politika/energijas_tirgus_un_infrastruktura/normativo_aktu_projekti/

3. Lassila J., Kaipia T., Lohjala J. New investment strategies in the modern electricity distribution business - reliability in the long-term planning. Proceedings of Power Engineering Society General Meeting, 24-28 June 2007, Tampa. P. 1-8.

4. Haakana J., Lassila J., Kaipia T., Partanen J. Underground cabling strategies in a rural area electricity distribution network. Proceedings of 20th International Conference and Exhibition on Electricity Distribution (CIRED 2009), 8-11 June 2009, Prague. Part 1. P. 1-4.

5. Langset T., Trengereid F., Samdal K., Heggset J. Quality dependent revenue caps - a model for quality of supply regulation. Proceedings of 16 th International Conference and Exhibition on Electricity Distribution (CIRED), 18-21 June 2001, Amsterdam. Part 1: Contributions. IEE Conference Publication 482. Vol. 6. P. 1-5.

6. Lvov A., Priedite-Razgale I., Rozenkrons J., Kreslins V. Assessment of different power line types' life-time costs in distribution network from reliability point of view. Proceedings of Electric Power Quality and Supply Reliability Conference (PQ), 11-13 June 2012, Tartu, Estonia. P. 1-8.

7. Priedite-Razgale I., Lvovs A., Kreslins V. Analysis and comparison of distribution system costs, dependant on underground cable and overhead lines' fault probabilities and maintenance cost difference. Proceedings of the 12th International 
Conference on Probabilistic Methods Applied to Power Systems, 10-14 June 2012, Turkey, Istanbul. P. 786-791.

8. Runčs J. Pilsētu elektrisko tīklu optimizācija (in Latvian). Ph. D. dissertation. Riga, Latvia: Faculty of Power and Electrical Engineering, Riga Technical University, 2007.

9. Solver T. Reliability in Performance-Based Regulation. Licentiate Thesis. Stockholm, Sweden: Department of Electrical Systems, Royal Institute of Technology, KTH, 2005.

10. Oḷeinikova I., Krišāns Z. Metodikas un datorprogrammas izstrādāšana Latvenergo augstsprieguma un sadales tīklu patērētāju elektroapgādes shēmas (tajā skaitā apakšstaciju primārās shēmas) drošuma novērtēšanai (in Latvian). Report on results of the 2 nd phase of the 1st stage. Riga, Latvia: Institute of Physical Energetics, Latvian Academy of Sciences, 2002.

11. Kaur N., Gurdip S., Bedi M. S., Bhatti T. Evaluation of customer interruption cost for reliability planning of power systems in developing economies. Proceedings of 8th International Conference on Probabilistic Methods Applied to Power Systems, 12-16 September 2004, Iowa State University, Ames, IA. P. 752-755.

12. Karki N. R., Verma A. K., Mishra A. K., Shrestha J., Bhatkar M. Industrial customers' survey for outage cost valuation in a developing country. Proceedings of North American Power Symposium 2009. P. 1-6.

13. Allan R. N., Kariuki K. K. Factors affecting customer outage costs due to electric service interruptions. IEE Proceedings: Generation, Transmission \& Distribution. 1996. Vol. 153. Issue 6. P. 521-528.

14. L,vovs A., Mutule A. Estimation of power supply interruption costs for Latvian customers. Latvian Journal of Physics and Technical Sciences. 2013. Vol. 50. No. 3. P. 24-34.

15. Energo Forums (in Latvian). 2011. No. 3(31). http://www.latvenergo.lv/portal/page/portal/ Latvian/EnergoForums1/EF_3_2011.pdf [Accessed: February 15, 2012].

16. Information about Typical Load Diagrams of Different Customers. Database of Latvian DSO AS "Sadales tikls". http://www.st.latvenergo.lv/portal/ page/portal/Latvian/Sad_tikls/Tipveida+grafiki_jauns.htm [Accessed: March 15, 2012].
17. Statistics Database on Environment and Energy of Central Statistical Bureau of Latvia. http://www. csb.gov.lv/ dati/statistikas-datubazes-28270.html [Accessed: March 15, 2012].

18. Chowdhury A. A., Koval D. O. Power Distribution System Reliability: Practical Methods and Applications. New Jersey: John Wiley \& Sons, Inc. $2009.531 \mathrm{p}$.

19. Samdal K., Kjølle G., Brekke K. Incorporating short interruptions and time dependency of interruption costs in continuity of supply regulation. Proceedings of 20th International Conference on Electricity Distribution, Prague, 8-11 June 2009. P. 1-4.

20. Horak J. Power quality: measurements of sags and interruptions. Proceedings of 2005/2006 IEEE PES Transmission and Distribution Conference and Exhibition, Dallas, TX, 21-24 May 2006. P. 733-739.

21. Nam K., Choi S., Ryoo H., Jeong S., Lee J., Kim D. A survey on interruption costs of Korean industrial customers. Proceedings of 2005/2006 IEEE PES Transmission and Distribution Conference and $E x$ hibition, Dallas, TX, 21-24 May 2006. P. 781-787.

22. Zviedritis M., Gavrilovs A., Kutjuns A. Power supply reliability vs. profitability in rural distribution networks. Proceedings of Electric Power Quality and Supply Reliability Conference (PQ), Rakvere, 11-13 June 2014. P. 335-340.

23. Krēslin̦š V. Nenodotās elektroenerğijas izmaksas noteikšana pie patērētāju ierobežošanas (in Latvian). Rīga: Rīgas Politehniskais Institūts, 1976.

24. Raesaar P., Tiigimagi E., Valtin J. Assessment of electricity supply interruption costs in Estonian Power System. Oil Shale. 2005. Vol. 22(2). P. 217-231.

25. Moldrik P., Gurecky J., Krejci P., Paszek L. Problems of deployment of RC switching elements in distribution MV networks for improving reliability of power supply. Proceedings of 9th International Conference on Electrical Power Quality and Utilisation (EPQU), 9-11 October 2007, Barcelona. P. 1-6.

26. Budahs M. AS "Sadales tìkls" modernizācija un attīstības perspektīvas" (in Latvian). AS "Sadales tîkls" Modernization and Development Perspectives. 2011. http://konferences.db.lv/arhivs/energetikas-forums-2011/ [Accessed: February 4, 2012].

27. Protection Zone Law. http://www.likumi.lv/doc. php?id=42348 [Accessed: April 10, 2012].

28. Information on Costs of Connection to the Network. Web page of Latvian DSO "Sadales tìkls". 
http://www.sadalestikls.lv/files/newnode/pieslegumi/ pieslegumieur/2014-04-08_sludin_vid_izm_2013g (EUR_LVL).pdf [Accessed: January 22, 2015].

29. Energo Forums (in Latvian). 2011. No. 3(31). http://www.latvenergo.lv/portal/page/portal/ Latvian/EnergoForums1/EF_3_2011.pdf [Accessed: February 15, 2012].

30. Lietotāju tipveida slodžu grafiki (in Latvian). Information about Typical Load Diagrams of Different Customers. Database of Latvian DSO AS "Sadales tikls". http://www.st.latvenergo.lv/portal/page/portal/Latvian/Sad_tikls/Tipveida+grafiki_jauns.htm [Accessed: January 20, 2015].

31. Latvian TSO Web Page with Information on Balancing Prices in Latvia in Year 2014. http://www. ast.lv/lat/elektroenergijas_tirgus/balansesana/ [Accessed: January 25, 2015].

32. Information on Historical Market Data on Elspot Monthly Prices in Year 2014 for Latvia. Nord Pool Spot Web Page. http://www.nordpoolspot.com/ [Accessed: January 25, 2015].

Aleksandrs L,vovs, Ilze Priedite

SKIRSTOMOJO TINKLO, SUDARYTO IŠ POŽEMINIŲ KABELIŲ IR ORO LINIJŲ, PATIKIMUMO DIDINIMO SĄNAUDŲ IR NAUDOS VERTINIMAS LATVIJOS PAVYZDŽIU

\section{Santrauka}

Vis dažnesni atšiaurių oro sąlygų pasireiškimo atvejai, sukeliantys skirstomųjų tinklų gedimus plačiu mastu, ypač kaimo vietovėse, verčia svarstyti klausimą dèl perejimo prie patikimesnio elektros skirstymo. Skirstomųų sistemų operatoriai ir nacionalinès reguliavimo institucijos turi rasti ne vien reikiamo patikimumo užtikrinimo sprendimą - jis kartu turi atitikti pakankamai pigią tolesnę skirstomųų tinklų plètrą. Taigi reikia rasti optimalų elektros energijos tiekimo patikimumo didinimo būdą.

Vienas iš sprendimų, leidžiančių veiksmingai mažinti gedimų skaičių, yra kabelinis tinklas. Tokio sprendimo investicinès sąnaudos yra gana didelès, palyginti su kitų tipų tinklo linijomis, dèl to kabeliavimo sprendimai visada kelia diskusijų dèl ekonominio pagrịstumo.

Šiame straipsnyje pateikiami sąnaudų ir naudos vertinimo būdai naujoms elektros linijoms ir vartotojų išlaidoms dèl didesnio elektros tiekimo patikimumo. Vertinimas apima visą linijų darbo amžiaus laikotarpi. Nustatomas vartotojų apkrovų kintamumas ir gedimų sąnaudos (autoriai apie tai rašè $[6,7]$ ), taip pat elektros tiekèjų (pardavèjų) nuostoliai dèl nepatiektos energijos.

Straipsnyje pateikiamas Latvijos pavyzdžio tyrimas. Jis grindžiamas realiomis Latvijos vartotojų išlaidomis siekiant didesnio patikimumo (Fizikinès energetikos instituto informacija), Latvijos požeminių kabelių ir oro linijų gedimų statistika, išsamia informacija apie Latvijos elektros skirstymo linijų kapitalo, eksploatavimo ir gedimų šalinimo sąnaudas.

Raktažodžiai: sąnaudų ir naudos vertinimas, elektros skirstymo linijos, elektros sistemos ekonomika, elektros sistemos patikimumas 